\title{
Legal Constraints on the Indeterminate Control of 'Dangerous' Sex Offenders in the Community: The Spanish Perspective
}

\author{
Lucía Martínez Garay \& Jorge Correcher Mira*
}

\begin{abstract}
This article presents an overview of the legal regime provided in the Spanish system of criminal sanctions regarding the control of dangerous sex offenders in the community. It focuses on the introduction, in 2010 , of a post-prison safety measure named supervised release. We describe the context of its introduction in the Spanish Criminal Code, considering the influence of societal upheaval concerning dangerous sex offenders in its development, and also the historical and theoretical features of the Spanish system of criminal sanctions. We also analyse the legal framework of supervised release, the existing case law about it and how the legal doctrine has until now assessed this measure. After this analysis, the main aim of this article consists in evaluating the effectiveness and the proportionality of the measure, according to the principle of minimal constraints and the rehabilitative function of the criminal sanctions in Spanish law, stated in Article 25.2 of the Spanish Constitution.
\end{abstract}

Keywords: Supervised release, supervision, sex offenders, dangerousness, safety measures, societal upheaval, proportionality

\section{Introduction}

\subsection{Context: Societal Upheaval Surrounding Dangerous Sex Offenders and Political Reaction}

Attitudes towards violent sex offenders changed in Spain in the mid-2000s. Although this is a complex issue, because a broad range of political, social and structural factors shapes the control of risk groups, the influence of media controversies surrounding famous cases of dangerous sex offenders is probably one of the most important reasons for this evolution. In this sense, some cases received an unprecedented media coverage in Spain: for example, in 2008, the well-known case of a five-year-old girl called Mari Luz, raped and murdered by an ex-convict. Also in 2008, another ex-convict, released in 2007 from a prior prison sentence for sexual crimes against young girls, was sentenced again for reoffending. ${ }^{1}$ The sexual component of both crimes, and the age of the victims, created an atmosphere of societal upheaval (or 'social alarm' according to the Spanish concept), claiming for more control over dangerous sex offenders. The cases exposed provided the impetus towards the legal enactment of supervision schemes in the Spanish system of criminal sanctions.

However, the social alarm generated by these cases and its media coverage is part of a wider context in the Spanish criminal law-making during the past two decades: there has been a constant aggravation of the penalties and also of the conditions regulating their execution, which started a few years after the passing of the Spanish Criminal Code (CC) in $1995 .^{2}$ Sexual offences have been one of the fields where this punitive trend has manifested more clearly (some of the sexual crimes have been modified up to four times during the period 1995-2015, always with the aim of increasing penalties or punishing new conducts ${ }^{3}$ ). This intensification of the criminal punishment has also affected many other fields, especially the treatment of reoffenders (for example by transforming the reiteration of minor offences of theft and assault in an autonomous and more serious crime, and with the introduction of the multi-reoffence aggravation in the CC. ${ }^{4}$ This whole evolution has not been a response to escalating rates of violent crimes or criminal rates in general: on the contrary, it has gone parallel to a stagnation or even decrease in the offending rates in

Lucía Martínez Garay is a Senior Lecturer at the University of Valencia, Department of Criminal Law. Jorge Correcher Mira, Ph.D., is an Assistant Lecturer at the University of Valencia, Department of Criminal Law. This article is part of a comparative research project involving several European jurisdictions, of which the results are presented in this special issue. For further background of the theme and outline of the issue and individual articles, as well as the comparative analysis, see the contribution by Van der Wolf in this issue. This work is also part of the Research Project I+D 'Execution of penalties and safety measures. Criminal policies trends in the modern penal reforms' (DER 2013-48284-R), Ministry of Economy, Spanish Government. Head of the Project: Prof. Dr. Juan Carlos Carbonell Mateu (University of Valencia).

1. M. Salat Paisal, La respuesta jurídico-penal a los delincuentes imputables peligrosos: especial referencia a la libertad vigilada (2015), at 58-63.

2. J.L. Díez Ripollés, 'Rigorismo y reforma penal. Cuatro legislaturas homogéneas (1996-2011)', 142-3 Boletín Criminológico (2013).

3. It is possible to recognise this tendency in the following reforms done in the Spanish criminal law by the Criminal Code Reform Acts 15/2003, 5/2010 and 1/2015 (CCRA 15/2003,5/2010 and 1/2015). Specifically about sexual crimes, Reform of Sexual Offences Act 11/1999.

4. According to Act 11/2003, about measures in citizen security, domestic violence and social integration of foreigners. Cf. S. Aguado López, La multirreincidencia y la conversión de faltas en delito (2008). 
Spain. ${ }^{5}$ In fact, Spain appears as one of the countries with the lowest criminal rates in Europe (in general, and concerning violent offences), but among the ones with a highest prison population. ${ }^{6}$

This attitude of the government, named by Spanish doctrine as punitive populism, ${ }^{7}$ the main feature of which is the strengthening of the penal law as an electioneering option, is thought to give an answer to societal upheaval created by media controversies, but not based on serious analysis of the real problems and needs of the criminal policy. ${ }^{8}$ In terms of high-risk offenders, most of the legislative changes have focused on sex offenders, particularly those who commit crimes against minors. One response to the management of convicted sex offenders has been to develop control or supervision schemes that extend governmental control over offenders after the expiration of their prison sentences.

1.2 Legal Responses to Dangerous Sex Offenders What was the reaction of the public authorities to the growing alarm regarding dangerous sex offenders in 2008? After several drafts and unclear proposals, ${ }^{9}$ the Criminal Code Reform Act 5/2010 (CCRA 5/2010) introduced a safety measure, specifically focusing on post-prison control of dangerous offenders, named supervised release. It is a non-custodial preventive measure, based on the offender's dangerousness, which is imposed at the time of sentencing together with the penalty for the crimes committed, but to be executed after the prison term. The period of post-prison supervision may last between one and ten years (non-indeterminate supervision). It is important to note that the supervised release was introduced both for sexual offenders and for terrorists, with a nearly identical regulation regarding its content, requisites and executing conditions. Nevertheless, for the purpose of this article, we will focus only on the case of sexual offenders.

5. Cf. E.G. España, J.L. Díez Ripollés, F.P. Jiménez, M.J.B. Jiménez and A.I.C. Domínguez, ‘Evolución de la delincuencia en España: Análisis longitudinal con encuestas de victimización', 8 Revista Española de Investigación Criminológica (2010).

6. According to Eurostat reports, where sexual crimes are included in violent crimes, available at: <http://ec.europa.eu/eurostat/statisticsexplained/index.php/File:Violent_crimes_recorded_by_the_police, $2002 \%$ E2\%80\%9312_YB14.png>. About prison population, available at: <http://ec.europa.eu/eurostat/statistics-explained/index.php/File: Prison_population,_2002\%E2\%80\%9312_YB14.png>.

7. L. Pozuelo Pérez, La política criminal mediática. Génesis, desarrollo y costes (2013); A.I. Cerezo Domínguez, El protagonismo de las víctimas en la elaboración de las leyes penales (2011); M. García Arán, J. Botella Corral \& R. Rebollo Vargas, Malas noticias: Medios de comunicación, política criminal y garantías penales en España (2009); M. García Arán, ‘El discurso mediático sobre la delincuencia y su incidencia en las reformas penales', Revista catalana de seguretat pública (2008).

8. D. Varona Gómez, 'Medios de comunicación y punitivismo', InDret (2011); see also 'Somos los españoles punitivos? Actitudes punitivas y reforma penal', InDret (2009); S. Soto Navarro, 'La influencia de los medios en la percepción social de la delincuencia', 7 Revista Electrónica de Ciencias Penales y Criminología (2005).

9. About these previous drafts, L. Martínez Garay, 'La libertad vigilada: regulación actual, perspectivas de reforma y comparación con la Führungsaufsicht del derecho penal alemán', 22 Revista General Derecho penal (2014); P. Otero González, La libertad vigilada aplicada a ¿imputables? Presente y futuro (2015); Salat Paisal, above n. 1.
This article aims to provide a description of its nature, legal framework, and an evaluation of its proportionality according to the principle of minimal constraints and from the perspective of rehabilitation as the objective of the Spanish system of criminal sanctions. ${ }^{10}$ As we will see in the following, although it was introduced with a limited scope, its introduction supposed a new paradigm in the Spanish system of criminal sanctions.

However, before going into details about the supervised release, we mention two other recent preventive measures enacted to control dangerous sex offenders in the community. The first measure is the Protection of Infancy Act 26/2015. It has stated the absence of criminal records concerning sexual crimes as a condition of acceding to labour activities related to regular contact with underage. ${ }^{11}$ In order to verify this requirement, a negative certification of the Central Register of Sex Offenders shall be handed over. According to the Protection of Infancy Act 26/2015, this Register should include data related to the identity and genetic profile of people sentenced for sexual crimes. However, in accordance with Article 10 of Order 1110/2015, based on which this Register was developed, criminal records could not be cancelled for a thirty-year period. This is a stricter legal framework than the general one contained in the CC with regard to criminal records, strengthening its stigmatising nature for sexual offenders.

The second measure related to the control of sex offenders is Article 129 bis CC, created by the CCRA 1/2015, which enables the Courts to ask for a DNA sample and introduce it in a police database in case of people convicted of serious crimes, if the Court appreciates that there is a high risk of reoffending. Although this provision concerns all serious crimes that may suppose risks for life, health or physical integrity, not only sexual crimes but also the official justification for this provision comes from the perspective of its necessity according to the Council of Europe Convention on the Protection of Children against Sexual Exploitation and Sexual Abuse, 25 October 2007. This reference is introduced to show how the scope of supervision of dangerous sex offenders in the community includes different fields of social control. In this sense, sex offenders may be subject to controls imposed by a number of provisions, which do not relate directly to their criminal conduct.

\section{Evaluation in Light of Sentencing Theory}

\subsection{Historical Approach}

The Spanish system of criminal sanctions has traditionally been organised as a 'twin track' system, according to

10. According to Art. 25.2 Spanish Constitution: 'Prison sentences and safety measures shall be oriented towards re-education and social rehabilitation.'

11. J. Tamarit Sumalla, 'La prueba de no ser pederasta: ¿una medida necesaria y proporcionada?', 96 Actualidad jurídica Aranzadi (2016). 
continental legal culture. This type of system is based on imposing different sorts of penal sanctions according to the two main different functions of the Criminal Law: penalties (prison and fines) as deserved punishments for the wrongdoings, and safety measures as preventive means for avoiding reoffending in the future. The penalties are grounded in the offender's personal responsibility for the violation of law, while the security measures depend on the concept of dangerousness. ${ }^{12}$

Along most of the twentieth century, the Spanish system was a strict twin track system, where it was possible to impose both penalties and safety measures, simultaneously, upon the same subject and sometimes because of the same conduct. ${ }^{13}$ Safety measures were stated in special laws (first in the Vagrancy Act of 1933, later in the Dangerousness and Social Rehabilitation Act of 1970) that did not focus only on criminal dangerousness but were built upon the more wider concept of social dangerousness. This system was used during the years of Franco's Dictatorship not only to justify harsher punishments and discriminatory treatment without considering civil liberties or procedural rights in its application, for vagrants, prostitutes, alcoholics or homosexuals, but also as a means of controlling political dissent and social disturbance. Thus, the notion of dangerousness was misused with a moral and political purpose. By the time democracy arrived in the late 1970s, this strict twin track system was completely discredited, in part because it had proven absolutely ineffective to prevent crimes, and also because of some pronouncements of the Constitutional Court that pointed out severe objections to its legitimacy; especially regarding the complete infringement of basic principles of criminal law, such as legality or fair trial. ${ }^{14}$

The Spanish CC enacted in 1995 repealed the Dangerousness and Social Rehabilitation Act and decided not to continue with the strict twin track system. The new regulation did include some safety measures, but only as therapeutic measures applicable in cases of non-responsible persons or persons with diminished responsibility. Moreover, these safety measures were subject to strict limits of proportionality (the safety measure cannot last

12. About this concept, see Section 3.2

13. With regard to the evolution of the twin track system in Spanish criminal law, see, in chronological order: A. Urruela Mora, Las medidas de seguridad y reinserción social en la actualidad. Especial consideración de las consecuencias jurídico-penales aplicables a sujetos afectos de anomalía o alteración psíquica (2009); A.J. Sanz Morán, Las medidas de corrección y de seguridad en el Derecho penal (2003); C.M. Romeo Casabona, Peligrosidad y Derecho penal (1986); F.J. Muñoz Conde, 'Monismo y dualismo en el Derecho penal español', 6 Estudios penales y criminológicos, at 216-39 (1981-1982); J. Terradillos Basoco, Peligrosidad social y Estado de Derecho (1981); A. Jorge Barreiro, Las medidas de seguridad en el Derecho español: un estudio de la ley de peligrosidad y rehabilitación social de 1970 y de la doctrina de la sala de apelación de peligrosidad (1976).

14. It is remarkable about the position of the Constitutional Court, regarding the difficulties to harmonise the system of the Dangerousness and Social Rehabilitation Act of 1970 with the presumption of innocence, the principle of legality and the ne bis in idem rule. See Constitutional Court, 27 November 1985, no. 159/1985; Constitutional Court, 14 February 1986, no. 23/1986. See also T. Vives Antón, 'Constitución y medidas de seguridad', in La libertad como pretexto (1995), at 245-53. longer than the prison penalty would have done if the subject had been found responsible for the crime) and shaped according to the 'vicarious system' (the security measure is executed first, and the time when the measure is executed counts as the time of the prison term). The CC did not introduce any security measures that could be imposed on a fully responsible person in addition to the penalty and serving after the prison term. This rejection of the strict twin track system in 1995 can be seen, at least in part, as a logical consequence of the excesses committed during the Dictatorship, where dangerousness had frequently been an excuse to tighten social control over social and political dissent.

\subsection{Theoretical Evaluation}

The system of criminal sanctions stated in the Spanish CC of 1995 was initially accepted by Spanish doctrine, albeit with some significant exceptions. ${ }^{15}$ However, the situation has changed in the past years. There are now more authors in favour of introducing custodial or preventive measures for responsible dangerous offenders despite the fact that violent crimes have not increased in recent years. ${ }^{16}$ The repeal of the Dangerousness and Social Rehabilitation Act of 1970 was necessary in 1995 because of the many violations of procedural guarantees and individual rights that it contained, but this does not mean - so they say - that any dualistic or twin track system involves the infringement of the basic principles of the constitutional state. According to this position, imprisonment is not enough in cases of dangerous sex offenders, who still pose a relevant danger of reoffending at the end of their prison terms. It is necessary to complement the retributive track of imprisonment with the preventive track of safety measures. It is within this context that the scholarly discussion regarding the supervised release has to be placed.

Part of the doctrine considers that the introduction of the supervised release is the first step to correct the mistake committed in 1995 when the Spanish CC abandoned the strict twin track system. It has been argued ${ }^{17}$ that the absence of safety measures for dangerous offenders could have been one of the causes of the punitive populism described before: the continuous aggravations on the nature and duration of the penalties in the past fifteen or twenty years could have been hiding an

15. J. Cerezo Mir, 'Consideraciones político-criminales sobre el nuevo Código Penal de 1995', in Estudios jurídicos en memoria del profesor Dr. D. José Ramón Casabó Ruiz (1998).

16. Cf. above n. 6 .

17. $C f$., but with important differences depending on the author, Cerezo Mir, above n. 15, at 390; L. Gracia Martín, 'Las medidas de seguridad y de reinserción social', in Tratado de las consecuencias jurídicas el delito (2006), at 435-37, 457,469; J.M. Zugaldía Espinar, 'Medidas de seguridad complementarias y acumulativas para autores peligrosos tras el cumplimiento de la pena', 1 Revista de Derecho penal y Criminología, at 199 et seq. (2009); R.M. García Albero, 'Ejecución de penas en el proyecto de reforma. Estudio de un problema concreto: qué hacer con los reos habituales o reincidentes en los que subsiste la peligrosidad criminal tras el licenciamiento definitivo', in F.J. García, A. ManjónCabeza Olmeda \& A. Ventura Püschel (eds.), La adecuación del derecho penal español al ordenamiento de la Unión Europea: la política criminal europea (2009), at 135. 
incapacitation component, which had to be accomplished through the penalties, because there were no security measures to resort to. Without preventive or custodial measures that could be added to prison sentences in cases of dangerousness, harsher punishment has been a logical consequence of a deficient system of criminal sanctions.

This is the reason why some authors consider the introduction of the supervised release as a necessary return to the twin track system in the Spanish system of criminal sanctions. Moreover, supervised release has the advantage of being a non-custodial measure, where the cost that it carries for the individual upon which it is imposed is not so intense as in the case of other possible measures, such as preventive detention. Therefore, supervised release can be legitimated more easily as a necessary measure that does not imply disproportionate sacrifices of individual rights. ${ }^{18}$

However, among supporters of supervised release, there is also criticism: some worry whether the particular legal configuration it has received will permit it to be sufficiently efficient in preventing future crimes, ${ }^{19}$ and many argue that although its introduction was convenient because of the reasons stated earlier, it should have been accompanied by a relevant reduction in the prison terms existing in Spain. As we have explained earlier, the severity of criminal punishment in Spain is very high, and the long prison terms assigned to many crimes may well respond at least in part to incapacitation aims. Therefore, post-prison restrictions imposed to subjects who have been previously sentenced to long-term prison sentences, even if they are non-custodial, could suppose a disproportionate constraint of individual liberty, as well as a double sanction for dangerousness unfavourable to the subject. ${ }^{20}$

18. M.A. Boldova Pasamar, 'Consideraciones político-criminales sobre la introducción de la pena de libertad vigilada', in El Anteproyecto de modificación del Código penal de 2008. Algunos aspectos. 6 Cuadernos penales José María Lidón (2009), at 47,51; J.M. Zugaldía Espinar, '8.7. Medidas de seguridad', in J. Álvarez García (ed.), Estudio crítico sobre el Proyecto sobre el Anteproyecto de Reforma Penal de 2012 (2013), at 457, 481 ff; B.J. Feijoo Sánchez, 'La libertad vigilada en el Derecho penal de adultos', in J. Díaz-Maroto y Villarejo (ed.), Estudios sobre las reformas del Código penal (2011), at 217; I. Ortiz de Urbina Gimeno, 'La introducción de la libertad vigilada en el Derecho penal español: hay motivos para el escándalo?', XXII Jornadas de la Abogacía General del Estado sobre 'El nuevo código penal' (2010).

19. V. Magro Servet, 'La figura del agente de libertad vigilada en la reforma del código penal', 7318 Diario La Ley (2008) and J. Leal Medina, 'La pena accesoria de libertad vigilada en el anteproyecto de reforma del Código penal; una respuesta del carácter preventivo frente a los delitos sexuales graves', 7318 Diario La Ley (2010). In this sense, Navarro Frías is sceptic concerning the efficacy of the measure in sexual psychopath. I. Navarro Frías, 'Psicopatía y medidas de seguridad: el caso de los psicópatas sexuales y la libertad vigilada tras la última reforma del código penal', 105 Cuadernos Política Criminal, at 156-8 (2011).

20. A.J. Sanz Morán, 'La nueva medida de libertad vigilada: reflexión político-criminal', Libertas-Revista de la Fundación Internacional de Ciencias Penales, at 217 (2012); X. Etxebarría Zarrabeitia, '8.5 Medidas de seguridad y su ejecución', in J. Álvarez García (ed.), Estudio crítico sobre el Proyecto sobre el Anteproyecto de Reforma Penal de 2012, at 457 . Feijoo Sánchez, above n. 18, at 327; García Albero, above n. 17, at 687; J. del Carpio Delgado, 'La medida de libertad vigilada para adultos', 36 Revista de Derecho penal, at ep. IV (2012).
Nevertheless, supervised release has also received harsher criticism in the literature from two confronting positions. On the one hand, some authors consider that it is unnecessary given the low level of violent criminality and sexual offending rates in Spain. In addition to this, the above mentioned authors consider that the addition of safety measures to penalties are illegitimate, and even more if they are aimed, as it is in their opinion the case with supervised release, only at incapacitating and controlling the subject without offering help and guidance for a proper rehabilitation. They denounce that supervised release operates in practice as a prolongation of the penalty because it will function as a substitute for parole: by hindering the application of parole while serving the sentence and adding an extra time of penal control in the form of supervised release after the prison term. ${ }^{21}$ On the other hand, some authors have criticised the introduction of supervised release for opposite reasons: they say that a non-custodial measure will be insufficient to achieve an effective control of dangerous sex offenders in the community. They consider it a soft measure that gives no proper answer to the most serious cases of dangerous offenders. According to this position, it is necessary to introduce more restrictive measures in the Spanish system of criminal sanctions, even for custodial ones or an indeterminate supervision of sex offenders. $^{22}$

\section{Supervised Release for Dangerous Sex Offenders in Spanish Criminal Law}

\subsection{Legal Framework}

Since its enactment in 2010, supervised release is a noncustodial safety measure imposable for terrorism crimes (Art. 579 bis 2 CC) and sexual crimes (Art. 192.1 CC). In the recent reform of the CC (CCRA 1/2015), homicide (Art. 140 bis CC) and some cases of domestic violence (Art. 156 ter and Art. 173.2 CC) have also been

21. N. García Rivas, 'La libertad vigilada y el derecho penal de la peligrosidad', 16 Revista General de Derecho penal, at 10-27 (2011); Huerta Tocildo, 'Esa extraña consecuencia del delito: la libertad vigilada', in J. Álvarez García (ed.), Libro Homenaje al Profesor Luis Rodríguez Ramos (2013), at 135 ff.; M. Acale Sánchez, Medición de la respuesta punitiva. Tratamiento penal del delincuente peligroso (2010), at 187-214, and '8.4 Medidas de seguridad', in J. Álvarez García (ed.), Estudio crítico sobre el Proyecto sobre el Anteproyecto de Reforma Penal de 2012 (2013), at 433; I.F. Benítez Ortúzar, 'La nueva medida de seguridad de libertad vigilada aplicable al sujeto imputable tras el cumplimiento de la pena privativa de libertad: la admisión de los postulados del Derecho penal del enemigo por la LO 5/2010', 103 Cuadernos Política Criminal, at 111,118 (2011).

22. Cf. J.M. Silva Sánchez, 'El contexto del Anteproyecto de Reforma del Código Penal de 2008', in El Anteproyecto de modificación del Código penal de 2008. Algunos Aspectos, 6 Cuadernos penales José María Lidón (2008), at 24. See also J.L. Manzanares Samiego, 'La libertad vigilada', 7534 Diario La Ley (2010). 
included in this numerus clausus. ${ }^{23}$ Its legal framework is established in Article 106 of the CC, defined as 'submission to judicial control'. This control consists in a list of eleven rules of conduct that restrict some rights and liberties, among which the Court has the discretion to choose which ones are the most appropriate or accurate according to the situation of the offender. The rules that can be imposed, listed in Article 106.1 of the CC, are as follows: obligation to always be traceable by means of electronic devices that allow the subject to be located at all times; obligation to regularly appear at the place set by the Judge or Court; that of immediately reporting, within the term and by the means stated by the Judge or Court for that purpose, each change of residence or place or post at work; prohibition to leave the place of residence or a specific area without authorisations from the Judge or Court; prohibition to approach the victim, or his relatives or other persons determined by the Judge or Court; prohibition to communicate with the victim, or with his relatives or other persons determined by the Judge or Court; prohibition to visit specific areas, places or establishments; prohibition to reside in specific places; prohibition to carry out certain activities that may provide or afford him the chance to commit criminal offences of a similar kind; obligation to participate in educational programmes or in labour, cultural, sexual education or other similar training programmes; obligation to follow external medical treatment, or to submit to periodic medical inspection.

It is worth noticing that only the obligations to participate in educational programmes and in labour, cultural, sexual education or other similar training programmes, as well as the obligations to follow medical treatment or submit to periodical medical inspection have a therapeutic and rehabilitative orientation. The rest of the rules of conduct are all focused on the control of dangerous sex offenders in the community, be it by controlling the places where he stays or the activities he does, or by protecting the victims from further contact with the offender.

According to Article 192 of the CC, which specifies the legal provisions of supervised release in relation to sexual offences, the duration of the measure lasts between one and five years, or between five and ten years, depending on the crimes' seriousness. The imposition of the measure in cases of sexual crimes is mandatory, ${ }^{24}$ being only optional when just one crime has been com-

23. Supervised release can also be imposed on subjects who could not be charged for their crimes, no matter what kind of crime, by reason of insanity or drug or alcohol abuse. However, in these cases, the legal nature of supervised release is different: it is not a post-prison measure, but a substitutive criminal sanction in cases where the penalty could not be imposed or should be reduced because of the diminished responsibility of the subject.

24. Supreme Court, 11 November 2014, no. 768/2014, para. 3. mitted, the crime is not serious and a first offender has committed it. 25

Supervised release is imposed on the same sentence that imposes the prison penalty. However, its execution starts when the subject is released from prison, so it is a post-prison non-custodial measure. In fact, the content of the measure is not established in the sentence, but only when the person is released from prison. In this sense, the Court for Penitentiary Control (CPC), ${ }^{26}$ has to submit a proposal to the Judge or Court that imposed the sentence at least two months before the prison term ends. The proposal has to be done taking into account offender's evolution during the prison sentence, and especially the rehabilitation perspectives at the time of releasing from prison. Although the wording of Article $106 \mathrm{CC}$ could lead to the conclusion that the execution of the supervised release is always mandatory, in fact it depends on the existence of dangerousness, so that if the Judge or Court considers that a positive prediction of low risk of reoffending can be observed, the measure can be left ineffective from the start (Art. 106.3(c) CC). Moreover, once imposed, the supervised release can be modified in its content according to the evolution of the subject. Its duration can also be reduced if his/her evolution is positive, and the measure can cease anytime when it appears to be no longer necessary because it is possible to ensure a positive prediction of rehabilitation. These legal provisions suppose recognition of the requirements derived from the principle of proportionality, which allows the use of security measures only when necessary. A very similar provision regarding this requirement of necessity also applies to all other security measures applicable for non-responsible subjects or persons with diminished responsibility because of insanity or drug abuse (Art. 97 CC).

Spanish doctrine has pointed out that supervised release should have been restricted to cases where the offender could not access to parole. The admission to this penitentiary regime requires the existence of a positive prediction of rehabilitation. Consequently, if the subject does not show a negative prediction of rehabilitation, one of the conditions of supervised release, and it would

25. This concept had not previously been used in Spanish criminal law, so it raised doubts about its meaning. According to García Rivas, there are different possibilities to interpret the concept of the first offender: (a) subject who has not been sentenced previously for committing a crime; (b) subject who has been sentenced previously for a crime of a different nature and (c) subject who has been sentenced previously for a sexual crime but his criminal record has been cancelled. Cf. García Rivas, above n. 21 , at 4 . The CCRA $1 / 2015$ has modified this requisite for terrorist crimes (the law no longer refers to a 'first offender' but to a 'person who has committed an offence for the first time'), but has not changed the wording in Art. 192.1 CC.

26. It is a Court different from the one that imposed the sentence. In the Spanish judicial system, the Courts for Penitentiary Control (Juzgados de Vigilancia Penitenciaria) are responsible for supervising the decisions taken by the penitentiary authorities (for example about temporary release from prison) and are responsible for granting or denying parole. 
be possible to access to parole, it means that supervised release is not necessary in this case. ${ }^{27}$

Regarding the breach of the obligations or prohibitions during the execution of the supervised release, it is possible to distinguish two possibilities: if the breach is sporadic or occasional, the Judge or Court has the discretion to modify the rules of conduct imposed. On the opposite, if the breach is serious and repeated and it reveals an offender's will to not obey the rules of conduct, it is possible to prosecute the subject for the socalled crime of punishment break or non-compliance. It is worth noting that this crime of punishment break, regulated in Article $468 \mathrm{CC}$, is punished with a prison penalty of up to one year if the penal sanction breached is supervised release. Therefore, although supervised release is a non-custodial measure, it could easily turn into a deprivation of liberty if the offender breaches the obligations imposed, a circumstance that maybe could be frequent taking into account that the measure is supposed to be imposed upon especially dangerous subjects. After this description of the legal framework of the supervised release, it is noticeable that, besides the enumeration of the rules of conduct that the Judge or Court can impose as the content of the measure, there is a lack of regulation in the CC about the practical application of the measure. ${ }^{28}$ It is also important to remark that the execution of the supervised release is completely oriented to the substantive criteria of dangerousness prediction. The following points are focused on when analysing these issues.

\subsection{The Concept of Dangerousness in Spanish Criminal Law}

The concept of dangerousness has been very controversial in scholarly discussion. It has been stated that it is a 'very dangerous' concept because of the lack of enough empirical knowledge to predict further offences with accuracy. ${ }^{29}$ It has been pointed out that empirical studies prove the existence of a tendency to overvalue dangerousness, that is, to classify incorrectly as dangerous offenders who do not evidence violent behaviour afterwards (false positives). One reason for this tendency to overestimate dangerousness is the intrinsic limitations of any method for estimating dangerousness, be it clinical or actuarial. ${ }^{30}$ Another reason would be the societal upheaval created in cases of false negatives, which would facilitate that Judges or Courts tend to presume the existence of dangerousness even if there is not

27. See M.V. Sierra López, La medida de libertad vigilada (2013), at 144; Salat Paisal, above n. 1, at 349; J. Cid Moliné, 'La medida de seguridad de libertad vigilada (Art. 106 CP y concordantes)', in J.M. Silva Sánchez and N. Pastor Muñoz (eds.), El nuevo Código Penal. Comentarios a la reforma (2012)

28. For more details, see Section 3.3.

29. T. Vives Antón, 'Métodos de determinación de la peligrosidad', in Peligrosidad social y medidas de seguridad (La ley de peligrosidad y rehabilitación social de 4 de agosto de 1970) (1974). More recently, Sanz Morán, above n. 13, at 93, with some references regarding the concept, such as its stigmatising meaning or the problem of labelling.

30. L. Martínez Garay, 'La incertidumbre de los pronósticos de peligrosidad: consecuencias para la dogmática de las medidas de seguridad', InDret (2014) enough evidence to justify it. ${ }^{31}$ In this sense, the role that public opinion has, or should have, in influencing sentencing practice is controversial. Public opinion is frequently based on mistaken assumptions about the sentences actually imposed on offenders in practice.

The problems of the notion of dangerousness and the uncertainty of the violence risk assessments affect the legitimacy of any security measure, which is aimed at preventing future crimes by determinate persons. If dangerousness cannot be stated with enough certainty, the preventive function essential to this kind of criminal sanctions is not reached because its imposition upon people who will not offend in the future (false positives) makes the security measures unnecessary and therefore illegitimate. At the same time, failure to impose them on people who will commit further crimes (false negatives) does not provide any better security for society. In this sense, there is an assumption that sex offenders are at a higher risk of reoffending than other offenders, but this may not be necessarily true. There are of course problems with estimating rates of reoffending within this group, given that many sexual offences remain undetected or unreported, but the available research does not support the premise that sex offenders inevitably reoffend or that they are more likely to reoffend than other group of offenders. ${ }^{32}$

Dangerousness is a requirement to impose any safety measures in the Spanish system of criminal sanctions, and it is defined briefly in the CC as 'prediction about the future behaviour of the subject that states that he will probably commit new crimes' (Art. 95 CC). Note that this provision does not specify the intensity of this probability, nor the seriousness of the crimes that the subject is supposed to commit in the future. Concerning supervised release, Article 106 of the CC does not demand expressly an assessment of dangerousness as a requisite for imposing or executing this particular measure, but it can be deduced from the general requirement stated in Article $95 \mathrm{CC}$ and from the fact that, as we have explained before, if there exists 'a positive prediction of rehabilitation', the measure should be reduced in its duration or directly cancelled. However, requiring dangerousness as a requisite for imposing security measures does not suppose a protection for the offender if the regulation describing it is vague, and there are no clear legal provisions regulating its assessment. This is precisely the case with the legal provisions we have just referred to in these pages.

This uncertainty and the problems associated with it have not been corrected by the case law. On one side, the meaning of dangerousness or the ways to assess the risk of future reoffending or violent behaviour have not been a central issue for the courts. There can be found sentences in the Spanish Supreme Court case law that

31. Ibid. See also Sanz Morán, above n. 13, at 102-6, and, very detailed, G. Albrecht, 'Sinn und Unsinn der Prognose von Gewaltkriminalität', in W. Heitmeyer and H.G. Soeffner (eds.), Gewalt. Entwicklungen, Strukturen, Analyseproblemen (2004).

32. B. McSherry and P. Keyzer, Sex offenders and preventive detention. Politics, policy and practice (2009), at 24. 
do not even distinguish with enough clarity between criminal dangerousness and social dangerousness. ${ }^{33}$ Spanish courts usually derive the existence of dangerousness from to the seriousness of previous offences and from the fact that the mental illness suffered by the accused needs a medical treatment. ${ }^{34}$ To our knowledge, courts have not until now directly addressed the problem of the uncertainty of violence risk assessments, and they usually do not ask the therapeutic specialist to explain the methodology or technique used to reach their conclusion. Then, the role of mental health professionals in assessing risk is not clarified. Sometimes, the sentences do not even allow knowing whether the court demanded the opinion of therapeutic specialists about the necessity of imposing a security measure and whether their professional view was taken into consideration. As a result, the argumentation used in the case law to affirm the existence of dangerousness is very limited, and the object of the predictions of dangerousness is very indeterminate. It can be said that the assessments of dangerousness in Spanish case law are mostly founded in the Court's intuition and offer very few guarantees to act as an effective filter to orientate the imposition of safety measures. ${ }^{35}$

\subsection{Supervised Release in Practice}

A remarkable feature concerning the legal provisions governing supervised release is the lack of a legal regulation about the institutions or personnel in charge of the supervision. Nor the CC or any other law or regulation states that public agents (if any) are competent for the daily supervision and guidance of the subject, for controlling if he obeys the rules of conduct imposed in the sentence. Moreover, there is no special public agency responsible for the supervision, apart from the Judge or Court, and apart from the role played by the police. The fact that it is not known who has to assess the evolution of the offender's behaviour while the measure is being executed is a very important problem, given that in case of a positive evaluation during the execution of the measure, it should be cancelled or its duration reduced. Without clear information about it, Courts do not have enough basis to take a proper decision during the execution of the supervised release. The only legal provision regulating this matter is Article $98 \mathrm{CC}$, which states that the CPC should present to the Court, at least annually, a proposal to maintain or cancel the measure, or also to modify the rules of conduct imposed to the subject. To

33. In this sense, Supreme Court, 2 February 2011, no. 65/2011, where it is stated, 'the study of dangerousness is destined to anticipate the possibility that sentenced person commit new harmful facts to society, according to Art. 95 Criminal Code' (emphasis added).

34. It has to be noticed that, until 2010, security measures existed in Spain only for mentally ill offenders or offenders with drug or alcohol abuse, so the assessment of dangerousness always included some kind of mental disturbance.

35. A. Alonso Rimo, 'Medidas de seguridad y proporcionalidad con el hecho cometido (a propósito de la peligrosa expansión del derecho penal de la peligrosidad)', 24 Estudios penales y criminológicos, at 120 (2009); T. Manso Porto, 'Freiheit sentziehende Maßnahmen gegen gefährliche, strafrechtlich verantwortliche (Rückfall) Täter, Spanien', in H.-G. Koch (ed.), Wegsperren (2011), at 333. do this proposal, the CPC 'should take into account all the reports delivered by the therapeutics who assess the sentenced during the execution of the supervised release'. But the problem is precisely that the legal framework does not have any provision about who are the persons who are supposed to assess the subject, nor about the pertinent institution to control the development of the measure.

The only reference to supervised release in another legal provision different to the CC is Article 23 Act $840 / 2011$, which regulates the execution of community penalties, as well as the suspension and substitution of penalties. According to this Act, the Treatment Council of the prison in which the offender is serving his penalty has to elaborate a report about his evolution. This report is submitted to the CPC, and it constitutes the basis for the proposal that this court has to in turn address to the sentencing Judge or Court so that this report can determine the rules of conduct that will be the content of the supervised release in each case. But Act 840/2011 does not say who is in charge of the supervision once the execution of the safety measure starts. In fact, Act 840/2011 excluded non-custodial safety measures from the Penitentiary Administrations' scope of competence, but without commending their execution to another institution. Consequently, non-custodial safety measures as supervised release have been located in noman's land, without any legal provision concerning its practical development', ${ }^{36}$ and, as it has been said graphically, we have in Spain 'a supervised release without a supervisor'. ${ }^{37}$

In this context, the role of the case law in clarifying the practical application of the supervised release could be highly significant. Nevertheless, the brief period passed as the introduction of the supervised release in 2010 does not permit a proper analysis yet. Given that supervised release is imposed in cases where prison sentences are noteworthy, there is still not enough case law to assess the concretion of the measure by its development in action.

However, some conclusions can be drawn from the case law concerning the moment of the imposition of the measure, this is at the time of sentencing when the supervised release is stated as a post-prison safety measure. For example there have been doubts about the complementarity of the measure with some accessory penalties established in the CC. ${ }^{38}$ In this sense, Supreme Court n. 618/2014 and n. $347 / 2013^{39}$ have

36. J. Nistal Burón, 'La libertad vigilada postpenitenciaria proyectada en la reforma del código penal. La necesidad de un derecho de ejecución para esta medida de seguridad no privativa de libertad', 9 Revista Aranzadi Doctrinal (2014)

37. Manzanares Samaniego, above n. 22

38. In Spanish law, accessory penalties (that consist in the deprivation of rights other than liberty or property, and usually are prohibitions to exercise certain professions or public posts) are imposed on specific offences, attending to the nature of the crime or the gravity of the penalty. For example, in cases of domestic violence, the prohibition of approaching the victim is a usual accessory penalty. See Section 4.1.

39. Supreme Court no. 618/2014, paras. 1-2 and Supreme Court no. 347/2013, para. 2. 
stated the compatibility of the supervised release with the accessory penalty of 'prohibition of approaching to the victim', although this is one of the rules of conduct that according to Article $106 \mathrm{CC}$ can be part of the content of the supervised release. The Supreme Court considers that there is no duplicity in imposing the prohibition twice because each sanction (the accessory penalty and the supervised release) is based on different foundations. Moreover, the accessory penalty is executed during the prison sentence, while supervised release is strictly a post-prison criminal sanction. Nevertheless, this does not solve the problem that arises in cases where the duration of the secondary penalty is larger than the prison sentence, so duplicity could exist if during the execution of the supervised release, the prohibition of approaching the victim is established as one of the rules of conduct. ${ }^{40}$ Another problem that has been addressed by the Supreme Court case law is whether supervised release can still be imposed when the prison sentence is suspended. In this sense, Supreme Court $768 / 2014^{41}$ states the mandatory nature of the supervised release, given that its imposition is not based on the same foundations as imprisonment, according to the twin track system. Then, it must always be executed, even in cases where the prison sentence has been suspended. Consequently, supervised release is not considered suitable for an automatic suspension, excepting the cases where, according to offender's positive evaluation, Courts have the discretion to cancel it, according to a positive prediction of rehabilitation.

The exposed lack of legal provisions governing supervised release is an important clue to understand the very limited efficacy that can be expected of this measure from a preventive perspective. According to Sanz Morán, the success of supervised release 'depends basically on the economic effort done to satisfy the material and personal needs required to reach a proper function of this safety measure'. ${ }^{42}$ In this sense, comparative law shows how countries with post-prison measures similar to supervised release have developed an important material and human infrastructure to achieve successful results in the supervision and control of dangerous offenders in the community. ${ }^{43}$ This is not the case in Spain. ${ }^{44}$ Without the provision of adequate resources, there is danger in that, no matter how effective the legal framework is in theory, in practice the agencies concerned will simply be overwhelmed. If the Government

40. Otero González, above n. 9, at 98.

41. Supreme Court no. $768 / 2014$, para. 2.

42. Sanz Morán, above n. 20, at 217. In a similar sense, see Urruela Mora, above n. 13, at 259, and C. Vázquez González, 'Algunas cuestiones penales y criminológicas sobre la nueva medida de libertad vigilada', in J. Álvarez García (ed.), Libro Homenaje al Profesor Luis Rodríguez Ramos (2013), at 264

43. See e.g. The German regulation of the Führugsaufsicht, or the offender supervision agencies in the United States.

44. According to comparative (criminal) law, even though similar measures to control dangerous sex offenders in the community are mentioned in the parliamentary discussion to justify the introduction of supervised release, such as probation service in England or Führugsaufsicht in Germany, its legal provisions in Spanish law are not so concrete in its statement, nor in providing means to its successful development. is committed to providing an effective framework to manage dangerous sex offenders, it must be prepared to ensure that adequate resources are available. In fact, there is a remarkable disparity between the theoretical arguments defended by the Government to justify the passing of supervised release, in comparison with the real effort that Public Administrations are doing to achieve a successful application of the measure.

\section{Place of Supervised Release within the Sentencing System}

\subsection{Character of the Framework}

According to the legal provisions described previously, the legal nature of supervised release is to be a safety measure. However, some scholars claim that, despite its consideration in the CC as a safety measure, its real nature is arguable. For example Mapelli Caffarena says that it is not so evident that supervised release is a safety measure and not a penalty. In his view, the legislator was interested in qualifying it as a safety measure because it made it easier to justify its existence. In current times of harsher punishment, post-prison control of dangerous offenders in the community could be seen as 'reasonable' in crimes that create societal upheaval. In his opinion, supervised release is closer to a sort of continued parole, an institution with which it shares many similarities. ${ }^{45}$ In this sense, supervised release could be considered as a means to extend the duration of the sentence, given that the possibility of accessing parole in cases of dangerous sex offenders is so restrictive that, generally, it is possible to say that it is not admitted. Consequently, the period that the offender could have served as a parole, he continues inside prison, and when he finally comes out, he is supervised in a similar way, as it would have been the case under parole. That is why it has been said that supervised release is a parole's simple substitute, in cases where a long-term sentence is completely executed, without any kind of reduction in its duration. ${ }^{46}$

Considering the legal provisions governing supervised release, it shows noteworthy similarities with other legal frameworks in the CC. For example the rules of conduct established in the letters (e), (f), (g) and (h) of Article 106.1 $\mathrm{CC}^{47}$ are almost identical to some accessory penalties described in Article 48 CC. ${ }^{48}$ According to Article $57 \mathrm{CC}$, accessory penalties can be imposed as comple-

45. B. Mapelli Caffarena, Las consecuencias jurídicas del delito (2011), at 383. In a similar sense, Nistal Burón, above n. 36; S. Camara Arroyo, ‘La libertad vigilada: De la ley penal del menor al ordenamiento penal de adultos', 25 Revista jurídica Universidad Autónoma de Madrid, at 82 (2012)

46. Acale Sánchez, above n. 21, at 215.

47. Prohibition to approach or communicate to/with victims, his relatives or another person, or to visit specific areas, places or establishments.

48. See Section 3.3 
mentary penalties to prison sentence when the offender has been convicted of serious crimes such as homicide, assault, abortion, torture, sexual offences, theft and human trade. In order to impose these penalties, the Court should consider 'the seriousness of the offence or the offender's criminal dangerousness'. We have described previously the importance of dangerousness as the central criterion for imposing safety measures. It is noticeable that the CC uses the same criterion to impose both criminal sanctions. In this sense, there is some controversy in legal doctrine about the legal nature of these prohibitions and its compatibility with safety measures. ${ }^{49}$ It has been pointed out that the decision of the legislative in 1995, when the CC was passed, limiting safety measures to cases of mental illness or drug abuse, could have influenced the legal regulation of the accessory penalties. As the CC did not provide safety measures for fully responsible dangerous offenders, the possibility of imposing a control on sex offenders in the community was done indirectly using accessory penalties. Therefore, according to its content, finality and nature, accessory penalties have been considered by many authors substantially as safety measures. However, with the creation of supervised release in 2010, a security measure does now exist for responsible dangerous offenders in certain crimes. Consequently, this duplicity should be avoided because it is a very problematic issue from the ne bis in idem perspective.

\subsection{Alternatives for Prevention}

In Spain, penitentiary treatment for dangerous sex offenders was first implemented in Catalonia in 1996, ${ }^{50}$ and afterwards extended to the rest of the country. ${ }^{51}$ From 2009 onwards, it is complemented in some Catalonian prisons with pharmacological treatment, which includes a modality of treatment with testosterone inhibitor. However, it is always voluntary and requires the offender's certified consent. ${ }^{52}$ Its implementation in the Catalonian penitentiary system has been positive, given that according to official data about $50 \%$ of the sexual offenders participate in the programme. ${ }^{53}$

49. E.M. Souto García, 'Las prohibiciones de residir en determinados lugares o acudir a ellos como penas privativas de (otros) derechos en el código penal de 1995', 9 Revista de Derecho penal y Criminología, at 182 (2013); P. Faraldo Cabana, Las prohibiciones de residencia, aproximación y comunicación en el Derecho penal (2008), at 53, 63. Also, with regard to authors who consider accessory penalties to be safety measures, see I. Valeije Alvarez, 'La regulación de las penas accesorias en el Código penal de 1995', 60 Anuario de Derecho penal y ciencias penales (2007), at 245; Sanz Morán, above n. 13, at 235.

50. Catalonia is the only region in Spain with autonomous competences in managing the penitentiary system.

51. In the website of the Secretary of Penitentiary Institutions, there is an explanatory report, available at: <www.institucionpenitenciaria.es/web/ portal/Reeducacion/ProgramasEspecificos/agresoresSexuales.html>.

52. Official information about this programme is available at: <http:// justicia.gencat.cat/web/.content/enllacos/pdf/model_rehabilitacio_ presons_catalanes.pdf>, at 89

53. The offenders participating in the programme were 332 in 2012, 315 in 2013 and 306 in 2014, from a total number of condemned sex offenders of 672, 637 and 593, respectively (data available at: <http://justicia. gencat.cat/ca/departament/Estadistiques/serveis_penitenciaris/>).
The situation is different in the rest of Spain. Despite the fact that empirical research has proven that a significant percentage of sex offenders respond favourably to rehabilitation treatments received during prison sentence ${ }^{54}$ penitentiary treatment for sex offenders is not completely implemented in Spain: only about half of the prisons offer this kind of programme, and only around $10 \%$ of the inmates condemned for the commission of sexual offences participate in it. ${ }^{55}$

The offer of prison treatment programmes for sexual offenders is scarce, so are the possibilities of providing aid or guidance for these offenders once they are out of prison. A specific post-prison assistance for sexual offenders does not exist as such in Spain nowadays, except for some sporadic experiences such as the Circles of Support and Accountability, an initiative promoted by the Justice Department in Catalonia to ease the transition of offenders from institutional settings back to the community. This model has demonstrated that community volunteers, with training and professional support, can have a marked impact on the rates of reoffend-

54. O. Herrero, ¿¿Por qué no reincide la mayoría de los agresores sexuales?', 23 Anuario de Psicología Jurídica, at 72 (2013); Redondo-Illescas, '¿Sirve el tratamiento para rehabilitar a los delincuentes sexuales?', 4 Revista española de investigación criminológica (2006). This study revealed that the re-offending rates of sexual offenders who had participated in the prison treatment programme was lower than that of those who had not; S. Redondo-Illescas and V. Garrido Genovés, 'Efficacy of a Psychological Treatment for Sex Offenders', 20 Psicothema, at 4-9 (2008). Undoubtedly, there are some profiles in sexual offences whose treatment is more difficult, and consequently, there is a higher risk to re-offend; in this sense, Navarro Frías refers to 'sexual psychopath', Cf. Navarro Frías, above n. 19, at 132, and Feijoo Sánchez, above n. 18, at 229 to 'criminals with an overpowering intern tendency'. However, this could not be an excuse to reject treatment, given that in many groups it has been effective. For a general guidance to treatment of sexual offenders (not limited to the Spanish literature), see R.K. Hanson, G. Bourgon, L. Helmus \& S. Hodgson, 'The Principles of Effective Correctional Treatment also Apply to Sexual Offenders: a Meta-Analysis'. 36 Criminal Justice and Behavior, at 865-91 (2009); M. Schmucker and F. Lösel, 'Does Sexual Offender Treatment Work? A Systematic Review of Outcome Evaluations', 20 Psicothema, at 10-19 (2008); L.R. Reitzel and J.L. Carbonell, 'The Effectiveness of Sexual Offender Treatment for Juveniles as Measured by Recidivism: A Meta-Analysis', 18 Sexual Abuse: A Journal of Research and Treatment, at 401-21 (2006); F. Lösel and M. Schmucker, 'The Effectiveness of Treatment for Sexual Offenders: A Comprehensive Meta-Analysis', 1 Journal of Experimental Criminology 117, at 117-46 (2005).

55. The number of sex offenders participating in the treatment programme has varied in the period 2010-2013 from a minimum of 248 to a maximum of 384 per year, among a total number of inmates condemned for the commission of sexual crimes varying from 3081 to 3758 (data extracted from the Informes Generales de la Administración Penitenciaria 2010 to 2013, available at: <www.institucionpenitenciaria.es/ web/portal/documentos/publicaciones.html>. Gómez-Escolar offered the following data for 2009: 3.620 imprisoned in Spain for sexual offences, but only 569 were part of a treatment programme (P. Gómez-Escolar Mazuela, 'Tratamiento penal de la delincuencia habitual grave', 7094 Diario La Ley (2009), adding the example of a prison located in Villena (Alicante). In this prison, there were hundred persons sentenced because of sexual offences, but it was only possible to offer penitentiary treatment to ten imprisoned. Aguado López underlines (not only in sexual crimes, but in general criminality) that 'in Spain there is a lack of human and material means to develop a successful rehabilitative treatment (...) many times rehabilitative programmes are paralysed because of lack of economic resources'. S. Aguado López, 'Tratamiento penal del delincuente reincidente peligroso: ¿con medidas de seguridad o en la ejecución de la pena?', 102 La Ley penal, at ep. III.2. (2013). 
ing by sexual offenders deemed to be at high risk of reoffending. ${ }^{56}$

Scholar discussion has stressed the point that the Spanish system of criminal sanctions is more focused on achieving prevention by means of post-prison control measures such as supervised release, instead of offering support and guidance so that people could find some help in constructing a new life as law-abiding citizens. Even if a proper application of supervised release could be considered acceptable from the point of view of its proportionality, it should not be the only option to achieve the preventive perspective of criminal sanctions. There is a lack of alternative preventive means that seems to be in deep contrast to the wording of Article 25.2 of the Spanish Constitution, which states rehabilitation as a necessary aim of the prison penalties and of the security measures.

\section{Human Rights Perspective}

An analysis of the supervised release from the perspective of the legal framework established in the European Convention of Human Rights (ECHR) would probably not lead to consider this measure as a formal violation of the rights and civil liberties of the ECHR. In contrast with the Sicherungsvermahrung in Germany, ${ }^{57}$ supervised release is not a post-prison deprivation of liberty, but only a non-custodial safety measure. However, it is remarkable that during its passing in the Spanish system of criminal sanctions, no reference to the case Guzzardi v. Italy, ECtHR (1980), was done. In this sense, supervised release is a criminal sanction where the boundaries between deprivation and restriction of liberty could be quite vague in some cases, as we have exposed in the cases where a breach of the rules of conduct could lead to a crime of punishment break, regulated in Article 468 of the CC and punished with a prison penalty of up to one year if the penal sanction breached is supervised release. ${ }^{58}$ As long as Guzzardi v. Italy, ECtHR (1980), is a common place about this discussion, it is debatable that there is a lack of attention by Spanish law to this case in the passing of supervised release, especially taking into account the content of Article 5 ECHR. In this sense, it is also remarkable that there is a lack of referen-

56. T. Nguyen, N. Frerich, C. García, C. Soler, S. Redondo-lllescas \& A. Andrés-Pueyo, 'Reinserción y gestión del riesgo de reincidencia en agresores sexuales excarcelados: el proyecto "Círculos de Apoyo y Responsabilidad" en Cataluña', 151 Boletín Criminológico (2014). The aim of this programme is to strengthen human and social values, from the development of abilities and personal resources to achieve welfare, as well as to ease rehabilitation and avoid re-offending. About its implementation in England, see R.J. Wilson and D.S. Prescott, 'CommunityBased Management of Sexual Offender Risk: Options and Opportunities', in Responding to sexual offending. Perceptions, risk management and public protection (2014), at 39.

57. Regarding this measure, it is possible to remark the case $M$ v. Germany, ECHR (2009), with respect to the incompatibility of the retroactive application of Sicherungsverwahrung in Germany, taking into account Arts. 5 and $7 \mathrm{ECHR}$.

58. See Section 3.1 ces to this leading case with regard to the distinction between Articles 5 and 2 (freedom of movement) from 4th Protocol, concerning the circumstances that could justify a restriction of liberty and its distinction from the deprivation of liberty. ${ }^{59}$ In this context, it could be pointed out that Spain has sometimes been reluctant to take into consideration the case law of Strasbourg's Court, especially concerning criminal sanctions. An example of this tendency is the political reactions to the case $D e l$ Rio Prada v. Spain ECtHR (2013). In this statement, the ECtHR sentenced Spain for a violation of Article 7 $\mathrm{ECHR}$, in relation to the principle of legality, because of the pronouncement by the Supreme Court of the socalled Parot Doctrine. ${ }^{60}$ In order to obey the statement declared in Del Río Prada v. Spain ECtHR (2013), in the months following the pronouncement many offenders who were still imprisoned because of the application of the Parot Doctrine were released. This release generated, especially in the case of dangerous sex offenders and terrorists, a societal upheaval because of the sensationalist media coverage of the facts. In this sense, there was a special persistence in remarking the high risk of reoffending.

\section{Conclusion}

Criminal justice systems have battled with the perennial issue of what to do with dangerous offenders and their potential for reoffending. Control of dangerous sex offenders in the community is provided in Spanish law by means of supervised release. Its introduction in the Spanish system of criminal sanctions has supposed a return to the strict twin track system that had been the traditional one in our country during the twentieth century. If this measure had been accompanied by a reduction in the existing prison terms, or it had been regulated according to the requirements of the proportionality principle, and inspired by a rehabilitative perspective, it could perhaps be considered a step forward in Spanish criminal law. However, attending to the political circumstances that surrounded its passing, and the concrete shape it has been given in the current regulation, there is serious reason to doubt it.

Societal upheaval was the main reason to justify the introduction of supervised release as a way to control dangerous sex offenders. When the Government established this measure, it was not thinking about the coherence of the Spanish system of criminal sanctions, nor

59. 'The difference between deprivation of and restriction upon liberty is nonetheless merely one of degree or intensity, and not one of nature or substance.' Guzzardi v. Italy, ECHR (1980), para. 93.

60. Supreme Court stated Parot Doctrine (the doctrine received its name because it concerned the case of Henri Parot, member of the terrorist group ETA) in 2006. The sentence established a new method to calculate reductions in sentence obtained through work and studies accomplished in prison, and its aim was to avoid reduction in prison sentences in cases of repeated commission of very serious crimes. Parot Doctrine was applied retroactively by Spanish courts, in a way that the ECHR considered contrary to the principle of legality. 
about effective alternatives for preventing reoffending. In fact, supervised release represents a hurried response from the legislator based on harsher punishment and a demagogic use of dramatic cases by the mass media. In this context, it is undeniable that the introduction of the measure was not responding to a proper evolution of the Spanish system of criminal sanctions, but to the political interest in using the Criminal law as an electioneering option.

Consequently, the legitimacy of the measure is problematic when confronted with the Spanish Constitution. Article 25.2 states that, 'Prison sentences and safety measures shall be oriented towards re-education and social rehabilitation.' Supervised release has been conceived as a post-prison measure to merely control dangerous sex offenders, without a rehabilitative content in its development, as can be clearly seen from the list of rules of conduct established in the CC, the majority of which lack a re-educational or rehabilitative content. Our main argument is that legislative regimes that aim solely at removing offenders from the community or restricting their movements are resource intensive and may not succeed in reducing the rates of reoffending. Supervision schemes stretch the boundaries of the curtailment of liberty beyond the traditional criminal justice approach of state action based on the commission of a crime.

Supervised release functions as a substitute of parole in crimes, such as sexual offences, where access to parole is more restricted every time. ${ }^{61}$ According to the principle of proportionality, it would be more coherent to grant parole more generously in sexual offences, albeit carefully rethinking its content and supervision, focusing on a rehabilitative perspective. ${ }^{62}$ In this sense, control of dangerous sex offenders would be an undeniable feature, but it is also necessary to introduce measures that provide assistance and support to offenders in order to avoid reoffending during parole. Then, energy and resources should be spent to improve and expand sex offender penitentiary treatment programmes. This would decrease the number of people who the Courts believe should be supervised after their release from prison.

Concerning the practical application of supervised release, we stress the absolute lack of the material and human means necessary to implement the measure properly. This is the circumstance that makes the symbolic function of the measure appear more obvious. Despite its presentation as a solution to security claims in a context of societal upheaval, the authorities' indolence to develop its content correctly, as well as its economic unsustainability, emphasises its inefficacy. Therefore, we agree with the Group of Studies in Crim-

61. Tendency confirmed in the CCRA 1/2015, where sexual offenders are excluded from the exceptional legal framework of parole for first offenders (Art. 90.3 CC).

62. See J. Cid Moliné and B. Tébar, 'Libertad condicional y delincuentes de algo riesgo', 8 Revista Española de Investigación Criminológica, at 17 (2010). inal Policy (Grupo de Estudios de Politica Criminal) ${ }^{63}$ when they denounce that it has been the punitive populism dynamic the inspiration for introducing supervised release in the Spanish system of criminal sanctions: 'to invoke rehabilitative purposes to try to justify this legal framework is just an excuse to tighten (...) punitivism' ${ }^{64}$

63. Legal Group formed by jurists (scholars, judges, magistrates and prosecutors) focused on developing research and making reform proposals in criminal law from a progressive perspective (<www.gepc.es/web/>).

64. Grupo de Estudios de Política Criminal, Alternativas al sistema de sanciones penales: Nuevas penas y medidas y medidas restrictivas de Derechos (2012), at 15. In addition, Gómez-Escolar Mazuela, above n. 55, 'it is unfair to dismiss rehabilitation without having done a serious and continuous effort to keep this principle alive'. In a similar sense, Acale Sánchez for whom it is not honest to first give up the rehabilitative content of the prison penalties and then invoke rehabilitation to try to justify the addition of a new sanction that further limits the rights of the convicts. Acale Sánchez, above n. 21, at 212. 